\title{
Perbandingan keefektifan pembelajaran berbasis proyek dan pembelajaran berbasis masalah ditinjau dari ketercapaian tujuan pembelajaran
}

\author{
Raoda Ismail \\ Program Studi Pendidikan Matematika, Universitas Cendrawasih. \\ Jalan Raya Sentani, Abepura, Jayapura, Papua, 99358, Indonesia. \\ * Corresponding Author. E-mail: raodaismail@gmail.com \\ Received: 3 September 2018; Revised: 17 October 2018; Accepted: 21 December 2018
}

\begin{abstract}
Abstrak
Penelitian ini bertujuan untuk mendeskripsikan keefektifan pembelajaran matematika dengan menggunakan model pembelajaran berbasis proyek dan model pembelajaran berbasis masalah, dan perbandingan keefektifan pembelajaran berbasis proyek dengan pembelajaran berbasis masalah ditinjau dari sikap percaya diri, pencapaian belajar matematika, dan keterampilan pemecahan masalah. Penelitian ini adalah penelitian eksperimen semu dengan desain kelompok pretes-postes beracak. Populasi penelitian ini adalah seluruh siswa kelas VIII SMP Negeri 9 Yogyakarta. Sampel penelitian sebanyak dua kelas yang dipilih secara acak. Data hasi penelitian dianalisis dengan MANOVA, dan untuk mengetahui keefektifan pembelajaran berbasis proyek dan pembelajaran berbasis masalah menggunakan uji one sample t-test. Hasil penelitian menunjukkan bahwa model pembelajaran berbasis proyek efektif ditinjau dari sikap percaya diri dan keterampilan pemecahan masalah namun tidak efektif ditinjau dari pencapaian belajar matematika; model pembelajaran berbasis masalah efektif ditinjau dari sikap percaya diri, pencapaian belajar matematika, dan keterampilan pemecahan masalah; dan pembelajaran berbasis masalah lebih efektif dari pembelajaran berbasis proyek ditinjau dari pencapaian belajar matematika.
\end{abstract}

Kata Kunci: pembelajaran berbasis proyek, pembelajaran berbasis masalah, sikap percaya diri, pencapaian belajar matematika, keterampilan pemecahan masalah

\section{The comparison of effectiveness of project-based learning and problem-based learning in terms of achievement of student's learning objectives}

\begin{abstract}
This study aims to describe: the effectiveness of teaching mathematics using project-based learning and problem-based learning; and the comparison in the effectiveness between project-based learning and problem-based learning in terms of the attitude of confidence, achievement of learning mathematics, and problem solving skills. This study is a quasi-experimental study employing the pretestposttest nonequivalent group design. The research population comprised all year VIII students of SMPN 9 Yogyakarta. The sample consisted of two classes that were randomly established. The data were analysed by means of MANOVA, and to test the effectiveness of project-based learning and problembased learning using one sample t-test. The result of this study shows that: project-based learning is effective in terms of the attitude of confidence and problem solving skills but not effective in learning based on achievement of learning mathematics; problem-based learning is effective in terms of the attitude of confidence, achievement of learning mathematics, and problem solving skills; and problembased learning more effective than project-based learning based on achievement of learning mathematics.
\end{abstract}

Keywords: project-based learning, problem-based learning, attitude of confidence, achievement of learning mathematics, problem solving skills

How to Cite: Ismail, R. (2018). Perbandingan keefektifan pembelajaran berbasis proyek dan pembelajaran berbasis masalah ditinjau dari ketercapaian tujuan pembelajaran. Pythagoras: Jurnal Pendidikan Matematika, 13(2), 181-188. doi:https://doi.org/10.21831/pg.v13i2.23595

https://doi.org/10.21831/pg.v13i2.23595 


\section{PENDAHULUAN}

Pembelajaran berbasis proyek merupakan pembelajaran otentik yang langsung melibatkan siswa dengan konten pembelajarannya. Hal tersebut senada dengan pernyataan Bender (2012, p.7) yang menyatakan bahwa pembelajaran berbasis proyek merupakan salah satu model yang paling efektif yang tersedia untuk melibatkan para siswa dengan konten pembelajaran mereka, dan untuk alasan itu, pembelajaran berbasis proyek sekarang direkomendasikan oleh banyak pemimpin pendidikan sebagai praktik pembelajaran terbaik.

Pembelajaran berbasis proyek memberikan pengalaman yang sangat baik bagi siswa dan dapat digunakan untuk mengulas pelajaran sebelumnya, maupun untuk mengawali pelajaran baru (Harmin \& Toth, 2006, p.337). Hal tersebut tercermin dalam langkah-langkah dari pembelajaran berbasis proyek. Tahapan-tahapan tersebut yaitu: (1) dimulai dengan pertanyaan penting; (2) mendesain rencana proyek; (3) membuat jadwal; (4) guru memantau siswa dan kemajuan proyek; (5) menilai hasil; dan (6) mengevaluasi pengalaman (Bender, 2012; Yusoff, 2006; Seidel \& Aryeh, 2002; Thomas, 2000; Fogarty, 1997).

Selain pembelajaran berbasis proyek, pembelajaran berbasis masalah (Problem-based Learning) juga menjadi salah satu rujukan model pembelajaran yang dapat merangsang siswa untuk aktif dalam pembelajaran. Pembelajaran berbasis masalah melibatkan para siswa dalam penyelidikan intelektual yang nyata dan relevan, dan memungkinkan mereka untuk belajar dari situasi kehidupan (Fogarty, 1997, p.2). Dalam pembelajaran berbasis masalah, dilakukan pemberian stimulus menggunakan masalah-masalah kontekstual. Melalui kegiatan pemecahan masalah, diharapkan keterampilan belajar dan pencapaian siswa dalam belajar dapat meningkat.

Pembelajaran berbasis masalah yang identik dengan penggunaan masalah dalam kegiatan pembelajaran dapat mengembangkan keterampilan pemecahan masalah, materi, dan pengaturan diri (Kauchak \& Eggen, 2012, p.307). Hal tersebut dapat dilihat dari langkah-langkah pembelajarannya yaitu: (1) menemukan masalah; (2) membangun struktur kerja; (3) menetapkan masalah; (4) mengumpulkan berbagai informasi;, (5) merumuskan solusi; dan (6) evaluasi (Fogarty, 1997; Tan, 2009; Kauchak \& Eggen, 2012; Mergendoller et al., 2007; Hosnan, 2014).
Pemecahan masalah merupakan salah satu keterampilan yang penting dalam kehidupan sehari-hari. Pemecahan masalah melibatkan berbagai proses termasuk menganalisis, menafsirkan, penalaran, memprediksi, mengevaluasi dan merefleksikan. Berdasarkan karakteristik kedua model pembelajaran yang telah dijabarkan, dapat dikatakan bahwa model pembelajaran berbasis proyek dan pembelajaran berbasis masalah samasama menekankan pada aspek pemecahan masalah. Oleh karena itu, salah satu tujuan pendidikan untuk melatih siswa menjadi pemecah masalah yang efisien juga menjadi tujuan dari pendidikan matematika (Karatas \& Baki, 2013).

Pemecahan masalah merupakan salah satu keterampilan praktis yang cukup umum dan bisa dipelajari. Keterampilan pemecahan masalah mencakup empat fase atau prinsipprinsip keterampilan antara lain (a) memahami masalah (tujuan, informasi yang diketahui dan yang tidak diketahui); (b) menyusun rencana atau solusi pendekatan; (c) melaksanakan rencana tersebut dan mengkonfirmasi kebenaran pelaksanaannya; dan (d) memeriksa solusi, memastikan hasilnya serta mempertimbangkan apakah ada solusi yang menjadi alternatif lain yang mungkin (Ifenthaler $e t$ al., 2011, p.2; Polya, 1988, pp.214-226).

Pemecahan masalah menjadi salah satu bagian yang penting dalam pembelajaran matematika (NCTM, 2000, p.52). Namun, beberapa fakta yang ditemui di Indonesia menunjukkan bahwa rata-rata kemampuan pemecahan masalah matematis siswa masih rendah, baik di tingkat pendidikan menengah maupun pendidikan tinggi. Secara klasikal kemampuan pemecahan masalah matematis belum mencapai taraf minimal yang dianggap memuaskan atau kriteria ketuntasan belajar minimal yang telah ditentukan (Atun, 2006; Noer, 2007; Dwijanto, 2007). Tak hanya itu, daya serap siswa pada mata pelajaran matematika di SMP se-Kota Yogyakarta juga belum menunjukkan hasil yang memuaskan. Hasil tersebut dapat menjadi salah satu tolok ukur bahwa penguasaan konsep matematika siswa SMP di Kota Yogyakarta masih perlu ditingkatkan, khususnya pada materi bangun ruang. Adapun persentase daya serap materi bangun ruang sisi datar pada ujian nasional SMP di Kota Yogyakarta selama dua tahun berturut-turut disajikan pada Tabel 1 (BSNP, $2012 \&$ 2013). 
Tabel 1. Persentase Penguasaan Materi Soal Bangun Ruang SMP se-Kota Yogyakarta

\begin{tabular}{lcc}
\multirow{2}{*}{ Kemampuan yang diuji } & \multicolumn{2}{c}{ Tahun Pelajaran } \\
\cline { 2 - 3 } & $2011 / 2012$ & $2012 / 2013$ \\
\hline $\begin{array}{l}\text { Menyelesaikan masalah } \\
\text { yang berkaitan dengan } \\
\text { luas permukaan bangun } \\
\text { ruang. }\end{array}$ & 51,09 & 56,77 \\
$\begin{array}{l}\text { Menyelesaikan masalah } \\
\text { yang berkaitan dengan } \\
\text { volume bangun ruang. }\end{array}$ & 59,42 & 61,52 \\
\end{tabular}

Berdasarkan Tabel 1, dapat dikatakan bahwa penguasaan materi bangun ruang masih perlu ditingkatkan, baik pada submateri luas permukaan maupun volume bangun ruang. Masih rendahnya kemampuan siswa pada penerapan materi geometri dalam bentuk soal pemecahan masalah menjadi salah satu indikasi rendahnya pemahaman konsep siswa pada materi geometri.

Tujuan pendidikan matematika menurut Ernest (2004, p.125) terkait dengan kelompokkelompok sosial serta ideologi yang mendasarinya, baik secara umum maupun yang berkaitan langsung dengan matematika. Tujuan pendidikan dewasa ini bukan hanya berkaitan dengan pengembangan pengetahuan dan keterampilan yang mutakhir saja, tetapi juga dalam membentuk kompetensi siswa pada ranah afektif. Van de Walle (2010, p.3) menyatakan bahwa matematika saat ini tidak hanya membutuhkan keterampilan berhitung, tetapi juga kemampuan untuk berfikir dan berargumen matematis dalam rangka memecahkan masalah dan belajar ide-ide baru yang akan dihadapi siswa di masa depan.

Tujuan umum pembelajaran matematika yang dirumuskan oleh National Council of Teachers of Mathematics (NCTM, 1989, p.5) yaitu agar siswa: (1) belajar menghargai matematika; (2) percaya diri terhadap kemampuannya dalam mengerjakan matematika; (3) menjadi pemecah masalah matematika; (4) belajar untuk berkomunikasi secara matematis; dan (5) belajar untuk melakukan penalaran secara matematik. Berdasarkan pada hal tersebut, dapat dipahami bahwa tujuan dari pembelajaran matematika tidak hanya berorientasi pada perkembangan pengetahuan, tetapi juga pada perkembangan sikap dan keterampilan dalam matematika.

Salah satu aspek afektif yang turut memberikan kontribusi terhadap keberhasilan siswa dalam belajar matematika adalah percaya diri. Hanula menyebutkan bahwa percaya diri berpengaruh terhadap unjuk kerja siswa dalam pembelajaran matematika, dan dapat mendukung peningkatan prestasi belajar siswa dalam pembelajaran matematika (Yang, et al, 2014, p.3). Dengan adanya sikap percaya diri, siswa memiliki kemampuan untuk mengambil tindakan yang tepat dan efektif dalam berbagai situasi, sekalipun muncul tantangan baik dari diri sendiri maupun dari orang lain (Burton \& Platts, 2006, p.10). Pentingnya sikap percaya diri tidak hanya dibutuhkan dalam pembelajaran, tetapi juga dalam kehidupan masyarakat. Hal tersebut senada dengan pendapat Larson (2009, p.270) yang menyatakan bahwa selain berpengaruh terhadap prestasi siswa di sekolah, rasa percaya diri dapat pula mempengaruhi siswa dalam pergaulan sehari-hari di kehidupan sosial masyarakat.

Berdasarkan data yang diperoleh dari Trends in International Mathematics and Science (TIMSS, 2012, p.338), Indonesia berada pada peringkat 40 dari 45 negara dalam aspek percaya diri siswa pada pelajaran matematika. Fenomena ini terjadi tentunya dipengaruhi pula oleh beberapa permasalahan yang telah dikemukakan sebelumnya. Diperlukan suatu upaya untuk membantu siswa dalam mengembangkan sikap percaya dirinya, khusunya dalam pembelajaran matematika.

Hasil studi pendahuluan yang telah dilakukan di salah satu kelas VIII SMP Negeri 9 Yogyakarta juga memperlihatkan bahwa tingkat kepercayadirian siswa terhadap matematika masih perlu ditingkatkan. Hal tersebut tampak dari respon siswa ketika diberi soal terbuka. Sebagian besar siswa merasa tidak yakin dengan apa yang mereka kerjakan. Salah satu penyebabnya adalah kebiasaan siswa dalam belajar matematika, yakni hanya diberikan soal dengan tipe soal tertutup, sehingga ketika mereka menemukan soal terbuka dan mengetahui bahwa hasil akhir yang mereka peroleh tidak sama dengan teman yang lain, mereka menjadi tidak percaya diri dengan jawabannya sendiri. Beberapa siswa yang memiliki kemampuan akademik lebih tinggi cenderung menyalahkan teman yang menyelesaikan dengan cara yang berbeda. Pada akhirnya, siswa segera meminta guru untuk mengklarifikasi hasil mereka, tanpa mencari argumen yang kuat untuk mempertahankan hasil kerja mereka. Kemauan untuk merefleksikan pikiran juga belum terlihat karena siswa merasa enggan untuk mengoreksi kembali apa yang mereka kerjakan karena sudah merasa pesimis dengan jawaban yang mereka peroleh.

Berdasarakan latar belakang tersebut, diharapkan melalui pembelajaran dengan model pembelajaran berbasis proyek dan pembelajaran 
berbasis masalah, diharapkan sikap percaya diri (SPD) dan keterampilan pemecahan masalah (KPM) siswa dapat dikembangkan secara optimal sehingga berdampak positif pada pencapaian belajar matematika (PBM) siswa. Oleh karena itu, penelitian ini bertujuan untuk mendeskripsikan keefektifan model pembelajaran berbasis proyek dan pembelajaran berbasis masalah serta perbedaan keefektifan model pembelajaran berbasis proyek dan pembelajaran berbasis masalah ditinjau dari sikap percaya diri, pencapaian belajar matematika, dan keterampilan pemecahan masalah.

\section{METODE}

Penelitian ini merupakan penelitian eksperimen semu dengan desain pretest-posttest nonequivalen group design. Penelitian ini dirancang dengan melibatkan dua kelas eksperimen, yang masing-masing menerapkan model pembelajaran berbasis proyek dan pembelajaran berbasis masalah.

Subjek penelitian ini adalah siswa kelas VIII F dan VIII E SMP Negeri 9 Yogyakarta Tahun Ajaran 2014/2015 yang masing-masing terdiri dari 34 siswa. Adapun teknik pengumpulan data yang digunakan adalah dengan mengumpulkan data sebelum diberikan perlakuan dengan memberikan pretest pencapaian belajar matematika (PBM), keterampilan pemecahan masalah (KPM), dan angket sikap percaya diri (SPD) terhadap matematika kepada masingmasing kelas eksperimen; kemudian memberikan perlakuan kepada masing-masing kelas eksperimen, dengan melaksanakan pembelajaran menggunakan model pembelajaran berbasis proyek pada kelas eksperimen pertama dan pembelajaran berbasis masalah pada kelas eksperimen kedua; dan mengunpulkan data setelah diberikan perlakuan pada masing-masing kelas eksperimen dengan memberikan posttest PBM, KPM, dan angket SPD terhadap matematika. Berikut merupakan hasil estimasi reliabilitas dari ketiga instrumen tersebut.

Tabel 2. Estimasi Reliabilitas Instrumen

\begin{tabular}{lc}
\multicolumn{1}{c}{ Instrumen } & $\begin{array}{c}\text { Koefsien } \\
\text { Reliabilitas }\end{array}$ \\
\hline Sikap Percaya Diri & 0,600 \\
Pencapaian Belajar Matematika & 0,774 \\
Keterampilan Pemecahan Masalah & 0,726
\end{tabular}

Teknik analisis data yang digunakan adalah analisis deskriptif dan inferensial. Analisis deskriptif dilakukan untuk mendeskripsikan keadaan sebelum dan sesudah diberikan perlakuan pada kedua kelas eksperimen ditinjau dari masing-masing variabel terikatnya. Analisis inferensial dilakukan untuk mengambil kesimpulan berdasarkan data yang telah diperoleh selama proses penelitian berlangsung. Analisis inferensial ini terdiri dari uji keefektifan dan uji komparasi pembelajaran matematika.

Sebelum dilakukan analisis keefektifan, kriteria keefektifan telah terlebih dahulu ditentukan yakni berdasarkan keriteria pencapaian tujuan pembelajaran yang ditunjukkan melalui ketuntasan belajar siswa dalam pembelajaran matematika, yaitu nilai PBM dan KPM siswa mencapai nilai kriteria ketuntasan minimum $(\mathrm{KKM})$. Kriteria keefektifan jika ditinjau dari SPD siswa terhadap matematika adalah apabila skor SPD yang diperoleh siswa masuk pada kategori baik yaitu dengan skor lebih dari 68 .

Sebelum dilakukan analisis inferensial, uji asumsi harus terlebih dahulu dipenuhi. Uji asumsi yang harus dipenuhi adalah uji normalitas dengan menggunakan kriteria Chi square $X^{2}$ (Johnson \& Wichern, 2007, pp.182-183), dengan kriteria nilai $d_{i}{ }^{2}<X_{p}^{2}(0,5)$ mendekati $50 \%$ data dapat dikatakan berdistribusi normal multivariat. Selain itu, uji homogenitas kedua kelompok juga diuji menggunakan uji Box-M (Huberty \& Olejnik, 2006, p.41), dengan kriteria nilai signifikansi yang diperoleh lebih dari 0,05 , dapat dikatakan bahwa matriks kovarians kedua populasi tersebut homogen.

Setelah melewati proses uji asumsi, dilanjutkan dengan One sample t-test untuk menganalisis keefektifan dari kedua model pembelajaran ditinjau dari masing-masing variabel terikatnya. Sedangkan analisis perbedaan keefektifan antara kedua model pembelajaran dilakukan dengan uji Multivariate Analysis of Variance (MANOVA) $T^{2}$ Hotelling (Stevens, 2009, p.148). Taraf signifikansi yang digunakan pada uji keefektifan adalah 0,05 . Sedangkan uji univariat dilakukan dengan menggunakan Independent sample t test dengan taraf signifikansi 0,01 . Uji ini digunakan untuk melihat apakah model pembelajaran berbasis proyek lebih efektif dibandingkan dengan model pembelajaran berbasis masalah.

\section{HASIL DAN PEMBAHASAN}

Inovasi dalam pembelajaran matematika di sekolah memang sangat dibutuhkan. Salah satu inovasi yang dapat dilakukan oleh guru adalah penerapan suatu model pembelajaran yang mendukung pengembangan kemampuan berpikir. Akan tetapi, tidak ada jaminan bahwa suatu model pembelajaran yang ada efektif jika diterapkan 
pada setiap materi dalam pelajaran matematika. Oleh karena itu, perlu dilakukan uji coba berupa eksperimen. Dalam penelitian ini, diterapkan model pembelajaran berbasis proyek dan pembelajaran berbasis masalah pada materi pokok bangun ruang sisi datar kelas VIII SMP Negeri 9 Yogyakarta.

Dari hasil analisis data yang diperoleh sebelum perlakuan, kelompok pembelajaran berbasis proyek dan kelompok pembelajaran berbasis masalah yang menjadi sampel penelitian memiliki kesamaan rerata. Hal ini sesuai tujuan pengambilan sampel, yaitu memilih dua kelas yang homogen. Hasil dalam penelitian ini terdiri dari hasil uji keefektifan dan uji komparasi keefektifan antara dua kelompok eksperimen, yang menggunakan model pembelajaran berbasis proyek dan pembelajaran berbasis masalah. Hasil uji keefektifan dengan menggunakan one sample t-test disajikan pada Tabel 3.

Tabel 3. Hasil Uji Keefektifan Model

Pembelajaran Berbasis Proyek dan Model Pembelajaran Berbasis Masalah

\begin{tabular}{llll}
\hline \multicolumn{1}{c}{ Kelompok } & Variabel & \multicolumn{1}{c}{$\mathrm{t}$} & Sig. \\
Pembelajaran & SPD & 12,961 & 0,000 \\
Berbasis & PBM & $-0,049$ & 0,481 \\
Proyek & KPM & 7,003 & 0,000 \\
\hline Pembelajaran & SPD & 9,724 & 0,000 \\
Berbasis & PBM & 3,167 & 0,001 \\
Masalah & KPM & 4,397 & 0,000 \\
\hline
\end{tabular}

Berdasarkan hasil analisis terlihat bahwa pada variabel sikap percaya diri (SPD) dan keterampilan pemecahan masalah (KPM), nilai signifikansi yang diperoleh kurang dari 0,05. Hal ini menunjukkan bahwa model pembelajaran berbasis proyek efektif ditinjau dari sikap percaya diri dan keterampilan pemecahan masalah. Namun, untuk pencapaian belajar matematika siswa (PBM), nilai signifikansi yang diperoleh lebih dar 0,05. Hal ini berarti pembelajaran berbasis proyek tidak efektif jika ditinjau dari prestasi belajar siswa.

Hasil analisis menunjukkan pembelajaran matematika menggunakan model pembelajaran berbasis proyek efektif ditinjau dari sikap percaya diri dan keterampilan pemecahan masalah. Pembelajaran berbasis proyek mampu melibatkan siswa secara aktif dalam konten pembelajaran mereka (Bender, 2012, p.7). Melalui berbagai kegiatan penyelidikan dalam pembelajaran berbasis proyek, siswa dapat membangun pengetahuan mereka sendiri dalam upaya memahami konsep dengan lebih baik dan bermakna diban- dingkan dengan belajar melalui kegiatan menghafal (Muchib, 2018; Rahayu \& Hartono, 2016).

Tahapan pertama yang dimulai dengan pertanyaan penting yang bersifat open ended menciptakan situasi dimana para siswa mengetahui bahwa tidak hanya ada satu jawaban atau solusi. Tahapan selanjutnya mendesain rencana proyek. Siswa dapat merasa memiliki proyek tersebut ketika mereka memiliki peran aktif dalam penentuan rencana kegiatan. Tahapan ketiga yaitu membuat jadwal. Pada tahap ini diperlukan kesadaran bahwa perubahan jadwal bisa saja terjadi. Oleh karena itu, siswa harus sigap dalam menghadapi penyelesaian permasalahan mereka berupa perubahan jadwal yang bisa saja terjadi. Ketiga tahapan ini yang memberikan peluang kepada siswa untuk mengembangkan sikap percaya diri mereka.

Tahapan keempat yaitu guru memantau kemajuan siswa dan kemajuan proyek. Dalam tahap ini guru mengingatkan siswa bahwa setiap bagian dari proses adalah milik siswa dan membutuhkan keterlibatan total dari mereka. Tahapan ini sangat mendukung penguatan konsep siswa dalam materi bangun ruang sisi datar. Tahapan kelima dan keenam adalah menilai hasil dan mengevaluasi pengalaman. Tahap ini memungkinkan siswa untuk mengevaluasi kemajuan dan menghubungkan kemajuan tersebut dengan siswa lainnya. Penilaian dan refleksi adalah bagian yang sangat penting dari proses belajar. Memberikan umpan balik kepada siswa mengenai seberapa baik mereka memahami informasi dan apa saja yang mereka butuhkan untuk melakukan peningkatan berperan penting dalam memperkuat keterampilan pemecahan masalah. Pembelajaran berbasis proyek memberikan pengalaman yang sangat baik bagi siswa dan dapat digunakan untuk mengulas pelajaran sebelumnya, maupun untuk mengawali pelajaran baru (Harmin \& Toth, 2006, p.337).

Ketidakefektifan model pembelajaran berbasis proyek ditinjau dari pencapaian belajar matematika siswa diduga dikarenakan oleh ketersediaan waktu dalam menyelesaikan dan menganalisis tugas dari proyek yang diberikan. Fokus perhatian siswa tidak hanya tertuju pada proyek yang akan diselesaikan namun juga harus mempersiapkan dan menyelesaikan beberapa tugas dari beberapa mata pelajaran lain yang juga bersamaan dengan waktu penyelesaian proyek. Salah satu kelemahan dari model pembelajaran berbasis proyek adalah memerlukan banyak waktu untuk menyelesaikan proyek (Kemendikbud, 2013, p.218). 
Pada model pembelajaran berbasis masalah, hasil analisis pada Tabel 3 menunjukkan bahwa bahwa pada variabel sikap percaya diri, pencapaian belajar matematika,dan keterampilan pemecahan masalah memperoleh nilai signifikansi yang kurang dari 0,05 . Hal ini menunjukkan bahwa model pembelajaran berbasis masalah efektif ditinjau dari sikap percaya diri, pencapaian belajar matematika, dan keterampilan pemecahan masalah.

Pembelajaran matematika menggunakan model pembelajaran berbasis masalah efektif ditinjau dari masing-masing aspek yang diteliti, yakni sikap percaya diri, pencapaian belajar matematika, dan keterampilan pemecahan masalah. Penggunaan masalah sebagai fokus dalam pembelajaran, menjadikan pembelajaran berbasis masalah yang bercirikan penggunakan masalah efektif mengembangkan keterampilan pemecahan masalah, materi, dan pengaturan diri (Kauchak \& Eggen, 2012, p.307). Langkah-langkah pembelajaran menggambarkan keseluruhan kegiatan yang mampu memfasilitasi pengembangan berbagai kemampuan yang dimiliki siswa. Melalui kegiatan pemecahan masalah, siswa secara aktif menggunakan keterampilan menginterpretasi, menganalisis, mengevaluasi serta membuat kesimpulan berdasrkan argumen-argumen yang ada sehingga hal tersebut dapat berpengaruh secara langsung terhadap peningkatan kemampuankemampuan tersebut (Rahayu \& Hartono, 2016).

Adapun langkah pertama pada pembelajaran ini adalah menemukan masalah. Pada tahap ini siswa memahami permasalahan yang disajikan. Siswa dapat menyadari bahwa masalah tersebut adalah penting dan membutuhkan waktu dan perhatian untuk dipecahkan. Langkah kedua dan ketiga adalah membangun struktur kerja dan menetapkan masalah. Pada langkah ini, siswa membangun struktur kerja dengan mengungkapkan apa yang mereka ketahui dari permasalahan yang ada dan ide apa yang bisa digunakan untuk memecahkan masalah. Masalah tersebut selanjutnya dikemas dalam bentuk rumusan masalah.

Langkah keempat adalah mengumpulkan dan berbagi informasi. Langkah ini mendorong siswa untuk melakukan kegiatan pengumpulan dan berbagi informasi yang diperlukan dengan teman kelompoknya guna penyelesaian masalah. Langkah terakhir yaitu merumuskan solusi dan evaluasi. Siswa secara berkelompok merumuskan solusi bagi pemecahan masalah yang dihadapi. Proses perumusan solusi dilakukan secara kolaboratif dan kooperatif dengan menekankan komunikasi yang efektif dalam kelompok. Setiap langkah-langkah dalam pembelajaran berbasis masalah tersebut sangat membantu pengembangan keterampilan pemecahan masalah dan secara tidak langsung telah mendukung pengembangan sikap percaya diri siswa dalam pembelajaran matematika. pengembangan berbagai kemampuan ini tentu dapat menunjang prestasi belajar siswa. Dengan kata lain, dapat disimpulkan bahwa pembelajaran berbasis masalah dapat menunjang peningkatan prestasi belajar siswa (Farhan \& Retnawati, 2014).

Pengujian terkait perbedaan keefektifan antara model pembelajaran berbasis proyek dan pembelajaran berbasis masalah menggunakan uji multivariat $T^{2}$ Hotelling dengan bantuan SPSS 20 for Windows. Hasil analisis menunjukkan bahwa nilai signifikansi yang diperoleh kurang dari 0,05 , yakni sebesar 0,000. Dengan demikian, dapat disimpulkan bahwa terdapat perbedaan keefektifan antara kelas eksperimen pertama dan kelas eksperimen kedua ditinjau dari sikap percaya diri, pencapaian belajar matematika, dan keterampilan pemecahan masalah. Karena terdapat perbedaan keefektifan antara kedua model pembelajaran tersebut, maka untuk dapat menyimpulkan mana yang lebih efektif terlebih dahulu akan dilakukan pengujian menggunakan uji independent sample t-tets. Hasil uji tersebut disajikan dalam Tabel 4.

Tabel 4. Hasil Independent Sample t-test

\begin{tabular}{ccc} 
Variabel & $\mathrm{T}$ & Sig. \\
\hline SPD & 0,415 & 0,339 \\
PBM & $-2,406$ & 0,009 \\
KPM & 0,897 & 0,187
\end{tabular}

Berdasarkan Tabel 4, terlihat bahwa nilai signifikansi pada variabel pencapaian belajar matematika kurang dari 0,01 dengan nilai $\mathrm{T}$ hitung negatif. Hal ini menunjukkam bahwa pembelajaran menggunakan model pembelajaran berbasis masalah lebih efektif daripada pembelajaran menggunakan model pembelajaran berbasis proyek ditinjau dari pencapaian belajar matematika. Hal ini sesuai dengan hasil analisis deskriptif yang menunjukkan bahwa rata-rata pada kelas yang menggunakan model pembelajaran berbasis masalah lebih besar daripada kelas yang menggunakan model pembelajaran berbasis proyek.

Salah satu faktor yang menyebabkan pembelajaran berbasis masalah lebih efektif adalah karena dalam pembelajaran berbasis masalah, siswa yang belajar memecahkan suatu masalah akan menerapkan pengetahuan yang dimilikinya atau berusaha mengetahui pengetahuan yang 
diperlukan. Belajar dapat semakin bermakna dan dapat diperluas ketika siswa berhadapan dengan situasi tempat konsep diterapkan. Kemudian, dalam model pembelajaran berbasis masalah, siswa mengintegrasikan pengetahuan dan keterampilan secara simultan dan mengaplikasikannya dalam konteks yang relevan.

Hasil analisis deskriptif juga menunjukkan bahwa pembelajaran matematika dengan model pembelajaran berbasis proyek dan pembelajaran berbasis masalah berdampak positif terhadap sikap percaya diri, pencapaian belajar matematika, dan keterampilan pemecahan masalah. Hal ini terlihat dari kondisi awal siswa sebelum dan sesudah diberikan perlakuan. Berikut adalah hasil analisis dari kedua kelas ekperimen.

Tabel 5. Rerata Kelas PBP dan PBM

\begin{tabular}{ccccc} 
& \multicolumn{2}{c}{ Pembelajaran } & \multicolumn{2}{c}{ Pembelajaran } \\
Deskripsi & \multicolumn{2}{c}{ Berbasis Proyek } & \multicolumn{2}{c}{ Berbasis Masalah } \\
& Pre & Post & Pre & Post \\
\hline SPD & 76,12 & 80,53 & 78,09 & 79,88 \\
PBM & 39,53 & 74,94 & 43,29 & 79,29 \\
KPM & 35,59 & 83,26 & 31,53 & 81,56
\end{tabular}

Pembelajaran berbasis masalah yang digunakan dalam penelitian ini dimulai dengan menemukan masalah, menganalisis masalah, membangun struktur kerja, menetapkan masalah, mengumpulkan berbagai informasi, merumuskan solusi, dan mengevaluasi. Berdasarkan penjelasan dari paragraf sebelumnya bahwa dalam pembelajaran berbasis masalah siswa dapat mengembangkan inisiatif dalam bekerja, memotivasi internal untuk belajar, dan dapat mengembangkan hubungan interpersonal dalam bekerja kelompok.

Dalam model pembelajaran berbasis proyek, setiap anggota dalam kelompok menyelesaikan atau mempelajari bagiannya secara individu, berbeda dengan kelompok dalam pembelajaran berbasis masalah. Mereka mempelajari dan menyelesaikan begian mereka dan saling berbagi informasi dan solusi yang diperoleh oleh masingmasing anggota kelompok sebelum menentukan solusi terbaik. Sehingga mereka lebih percaya diri dan mempunyai rasa ingin tahu yang tinggi dalam pembelajaran.

\section{SIMPULAN}

Berdasarkan hasil analisis penelitian dan pembahasan yang dilakukan, dapat disimpulkan bahwa model pembelajaran berbasis proyek efektif ditinjau dari sikap percaya diri dan keterampilan pemecahan masalah, namun tidak efektif ditinjau dari pencapaian belajar matematika. Sedangkan model pembelajaran berbasis masalah efektif ditinjau dari sikap percaya diri, pencapaian belajar matematika, dan keterampilan pemecahan masalah. Terdapat perbedaan keefektifan antara model pembelajaran berbasis proyek dan pembelajaran berbasis masalah. Hasil perbandingan keefektifan keduanya menunjukkan bahwa model pembelajaran berbasis masalah lebih efektif dari model pembelajaran berbasis proyek ditinjau dari pencapaian belajar matematika.

Terkait hasil penelitian dan bentuk tindak lanjut dari penelitian ini, saran bagi peneliti lain yang ingin melakukan penelitian dengan model pembelajaran berbasis proyek dan pembelajaran berbasis masalah disarankan untuk meneliti halhal yang berkaitan dengan materi dan aspek afektif maupun kognitif yang benar-benar menjadi masalah di sekolah atau di kelas yang akan dijadikan tempat penelitian. Hal ini bertujuan agar upaya perbaikan yang dilakukan memberikan kontribusi positif secara langsung bagi siswa, guru, dan sekolah tempat penelitian dilakukan.

\section{DAFTAR PUSTAKA}

Atun, I. (2006). Pembelajaran matematika dengan strategi kooperatif tipe STAD untuk meningkatkan kemampuan pemecahan masalah dan komunikasi siswa SMA. Thesis. Universitas Pendidikan Indonesia.

Bender, W. N. (2012). Project-based learning: Differentiating instruction fot the $21^{\text {st }}$ century. Thousand Oals, CA: Corwin.

BSNP. (2012). Panduan pemanfaatan hasil UN untuk perbaikan mutu pendidikan. Jakarta: Pusat Penilaian Pendidik.

BSNP. (2013). Panduan pemanfaatan hasil UN untuk perbaikan mutu pendidikan. Jakarta: Pusat Penilaian Pendidik.

Burton, K., \& Platts, B. (2006). Building confidence for dummies. Sussex: John Wiley \& Sons, Ltd.

Dwijanto. (2007). Pengaruh pembelajaran berbasis masalah berbantuan komputer terhadap pencapaian kemampuan pemecahan masalah dan berpikir kreatif matematika mahasiswa. Disertasi. Universitas Pendidikan Indonesia.

Ernest, P. (2004). The philosophy of matematics education. London: Falmer Press.

Farhan, M., \& Retnawati, H. (2014). Keefektifan PBL dan IBL ditinjau dari prestasi belajar, 
kemampuan representasi matematis, dan motivasi belajar. Jurnal Riset Pendidikan Matematika, $\quad$ 1(2), 227240.doi:http://dx.doi.org/10.21831 /jrpm.v1i2.2678

Fogarty, R. (1997). Problem-based learning and other curriculum models for the multiple intelligences classroom. Thousand Oaks: Sage Publication Inc.

Harmin, M., \& Toth, M. (2012). Pembelajaran aktif yang menginspirasi: Buku pegangan lengkap untuk guru masa kini. (Terjemahan Bethari Anissa Ismayasari). Alexandria, VA: ASCD.

Hosnan, M. (2014). Pendekatan saintifik dan kontekstual dalam pembelajaran abad 21. Bogor: Ghalia Indonesia.

Huberty C.J., \& Olejnik S. (2006). Applied MANOVA and discriminant analysis. New Jersey, NJ: John Wiley \& Sons, Inc.

Johnson, R., \& Wichern D. W. (2007). Applied multivariate statistical analysis $6^{\text {th }}$ edition. New Jersey, NJ: Pearson Prentice Hall.

Karatas, B., \& Baki, A. (2013). The effect of learning environments based on problem solving on students' achievements of problem solving. International Electronic Journal of Elementary Education, 5(3), 249-268.

Kauchak, D., \& Eggen, P. (2012). Strategi dan model pembelajaran: mengajarkan konten dan keterampilan berpikir. Jakarta: Indeks.

Kemendikbud. (2013). Materi pelatihan guru implementasi Kurikulum 2013. Jakarta: Kemendikbud.

Larson, J. E. (2009). Educational psychology: Cognition and learning, individual differences and motivation. New York, NY: Nova Science Publisher, Inc.

Mergendoller, J. R., Maxwell, N., \& Bellisimo, Y. (2007). The effectiveness of problembased instruction: a comparative study of instructional methods and student characteristics. The Interdisciplinary Journal of Problem-based Learning, 1(2), 49-69.

Muchib, M. (2018). Penerapan model PBL dengan video untuk meningkatkan minat dan prestasi belajar bahasa Indonesia. Wiyata Dharma: Jurnal Penelitian dan Evaluasi Pendidikan, 6(1), 25-33. doi:http://dx.doi.org/10.30738/wiyata

dharma.v6i1.3356

NCTM. (1989). Curriculum and evaluation standards for school mathematics. Reston, VA: The National Council of Teachers of Mathematics, Inc

NCTM. (2000). Principles and standards school mathematics. Reston, VA: The National Council of Teachers of Mathematics, Inc.

Noer, H. S. (2007). Pembelajaran open ended untuk meningkatkan kemampuan pemecahan masalah matematik dan kemampuan berfikir kreatif. Tesis, tidak dipublikasikan. Universitas Pendidikan Indonesia.

Rahayu, E., \& Hartono, H. (2016). Keefektifan model PBL dan PjBL ditinjau dari prestasi, kemampuan berpikir kritis, dan motivasi belajar matematika siswa SMP. Pythagoras: Jurnal Pendidikan Matematika, $\quad 11(1), \quad 1-10$. doi:https://doi.org/10.21831/pg.v11i1.962 9

Seidel, S., \& Aryeh, L. (2002). Project-based and experiential learning in after-school programming. Cambridge: After-School.

Stevens, J. P. (2009). Applied multivariate statistics for the social sciences $5^{\text {th }}$ edition. New York, NY: Routledge Taylor \& Francis Group.

Thomas, J. W. (2000). A Review of research on project based learning. California: The Autodesk Foundation.

Tan, O. S. (2009). Problem-based learning and creativity. Singapore: Chengange Learning.

TIMSS. (2012). TIMSS 2011 International Results in Mathematics. Amsterdam: TIMSS \& PIRLS International Study Center.

Yang, D. C., Lai, M. L., Yao, R. F., \& Huang, Y. C. (2014). Effect of remedial instruction on low SES low math students' mathematics competence, interest and confidence. Journal of Education and Learning, 3(1), $1-13$.

Yusoff. (2006). Project-based learning handbook: Educating the millennial learner. Kuala Lumpur: Educational Technology Division Ministry of Education. 